\title{
TU/e EmonOWEN

\section{Influence of polymer chain architecture of poly(vinyl alcohol) on the inhibition of ice recrystallization}

\section{Citation for published version (APA):}

Olijve, L. L. C., Hendrix, M. M. R. M., \& Voets, I. K. (2016). Influence of polymer chain architecture of poly(vinyl alcohol) on the inhibition of ice recrystallization. Macromolecular Chemistry and Physics, 217(8), 951-958. https://doi.org/10.1002/macp.201500497

DOI:

10.1002/macp.201500497

Document status and date:

Published: 01/04/2016

\section{Document Version:}

Publisher's PDF, also known as Version of Record (includes final page, issue and volume numbers)

\section{Please check the document version of this publication:}

- A submitted manuscript is the version of the article upon submission and before peer-review. There can be important differences between the submitted version and the official published version of record. People interested in the research are advised to contact the author for the final version of the publication, or visit the $\mathrm{DOI}$ to the publisher's website.

- The final author version and the galley proof are versions of the publication after peer review.

- The final published version features the final layout of the paper including the volume, issue and page numbers.

Link to publication

\section{General rights}

Copyright and moral rights for the publications made accessible in the public portal are retained by the authors and/or other copyright owners and it is a condition of accessing publications that users recognise and abide by the legal requirements associated with these rights.

- Users may download and print one copy of any publication from the public portal for the purpose of private study or research.

- You may not further distribute the material or use it for any profit-making activity or commercial gain

- You may freely distribute the URL identifying the publication in the public portal.

If the publication is distributed under the terms of Article 25fa of the Dutch Copyright Act, indicated by the "Taverne" license above, please follow below link for the End User Agreement:

www.tue.nl/taverne

Take down policy

If you believe that this document breaches copyright please contact us at:

openaccess@tue.nl

providing details and we will investigate your claim. 


\title{
Influence of Polymer Chain Architecture of Poly(vinyl alcohol) on the Inhibition of Ice Recrystallization
}

\author{
Luuk L. C. Olijve, Marco M. R. M. Hendrix, Ilja K. Voets*
}

Poly(vinyl alcohol) (PVA) is a water-soluble synthetic polymer well-known to effectively block the recrystallization of ice. The effect of polymer chain architecture on the ice recrystallization inhibition (IRI) by PVA remains unexplored. In this work, the synthesis of PVA molecular bottlebrushes is described via a combination of atom-transfer radical polymerization and reversible addition-fragmentation chain-transfer polymerization. The facile preparation of the PVA bottlebrushes is performed via the selective hydrolysis of the chloroacetate esters of the poly(vinyl chloroacetate) (PVClAc) side chains of a PVClAc precursor bottlebrush. The IRI efficacy of the PVA bottlebrush is quantitatively compared to linear PVA. The results show that even if the PVA chains are densely grafted onto a rigid polymer backbone, the IRI activity of PVA is maintained, demonstrating the flexibility in PVA polymer chain architecture for the design of synthetic PVA-based ice growth inhibitors.
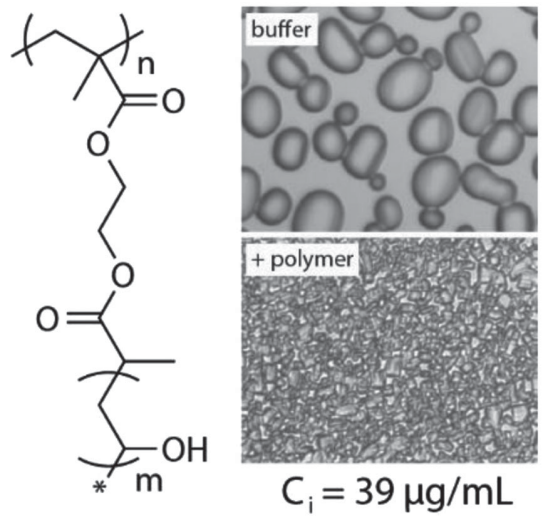

\section{Introduction}

Poly(vinyl alcohol) (PVA) is a water-soluble, nontoxic adhesive polymer and is widely used as thickener or modifier in paint and coating industries, surfactant or emulsifier

Dr. L. L. C. Olijve, Dr. I. K. Voets

Institute for Complex Molecular Systems

Eindhoven University of Technology

Post Office Box 513, 5600 MD

Eindhoven, The Netherlands

E-mail: i.voets@tue.nl

Dr. L. L. C. Olijve, Dr. I. K. Voets

Laboratory of Macromolecular and Organic Chemistry

Eindhoven University of Technology

Post Office Box 513, 5600 MD

Eindhoven, The Netherlands

M. M. R. M. Hendrix, Dr. I. K. Voets

Laboratory of Physical Chemistry

Department of Chemical Engineering and Chemistry

Eindhoven University of Technology

Post Office Box 513, 5600 MD

Eindhoven, The Netherlands in shampoos, and in biomedical materials such as contact lenses. ${ }^{[1-3]}$ PVA has furthermore been found to adhere to ice-surfaces and inhibit the recrystallization processes of ice, which withholds great potential in the development of innovative cryopreservation and anti-icing technologies. ${ }^{[4-7]}$ The efficient cryopreservation of human red blood cells by addition of only $0.1 \mathrm{wt} \%$ PVA was recently reported, which attained a significant increase in cell recovery. ${ }^{[8]}$ Compared to biological antifreeze polymers such as antifreeze glycoproteins (AFGPs), PVA has the advantage that it is inexpensive and can be produced in large quantities. The use of PVA in novel antifreeze formulations offers new methodologies to protect water-based products against ice formation and growth.

The physical-chemical properties of PVA depend significantly on the degree of polymerization, degree of hydrolysis, and stereochemistry of the main chain. ${ }^{[9-11]}$ Typically, PVA is prepared by the free radical polymerization of vinyl acetate (VAc), followed by hydrolysis of the atactic poly(vinyl ester) precursor. Despite huge effort and commercial interest, control over both molecular weight and stereochemistry is still considered a synthetic 
challenge in the synthesis of PVA. ${ }^{[12,13]}$ The significance of polymer molecular weight, stereochemistry, and side group functionality on antifreeze activity is evident from studies on the antifreeze activity of AFGPs. AFGPs found in the blood of marine fishes vary in molecular weight (2500-25 $000 \mathrm{Da})$, of which the high molecular weight fraction is much more active. ${ }^{[14]}$ Furthermore, minor changes in the configuration of the sugar moiety, and the presence of acetyl or methyl groups can significantly alter the antifreeze activity. ${ }^{[15,16]}$

The effect of molecular weight on the ice recrystallization inhibition (IRI) activity of PVA has been well described by Congdon et al. ${ }^{[6]}$ One unexplored research direction is the effect of main chain architecture on the IRI activity of PVA. Over the past two decades, advances in polymer sciences in living/controlled radical polymerization techniques have led to the design and synthesis of novel macromolecular architectures, such as block copolymers, branched and dendritic polymers, molecular bottlebrushes, etc. ${ }^{[17-20]}$ Molecular bottlebrushes are a class of copolymers with an extended rod-like topology due to steric repulsion of the densely grafted side-chains. ${ }^{[21]}$ These brush polymers have gained significant interest for applications ranging from super soft elastomers to stimuli responsive molecules because of their unique macromolecular architecture. Nese et al. developed an efficient procedure to prepare molecular brushes of VAc and other vinyl ester monomers, using a combination of atom-transfer radical polymerization (ATRP) and reversible addition-fragmentation chain-transfer (RAFT) polymerization. ${ }^{[22,23]}$ However, the PVAc side chains of the molecular brush could not be hydrolyzed to prepare PVA bottlebrushes due to the presence of multiple ester bonds.

In this work, the synthesis of PVA molecular bottlebrushes is described via the selective hydrolysis of chloroacetate esters of grafted poly(vinyl chloroacetate) (PVClAc) side chains. As a precursor for the brush backbone, poly(2hydroxyethyl methacrylate) (PHEMA) with narrow molecular weight distribution was prepared by ATRP, followed by esterification of the hydroxyl groups with xanthate moieties to form the macroCTA poly(2-propionyloxyethylxanthateetyl methacrylate) (PPXEM). PVClAc side chains were grafted on the PPXEM backbone using RAFT polymerization to generate PPXEM- $g$-PVClAc molecular bottlebrushes. The rate of chloroacetate ester cleavage is known to be 760 times faster than the cleavage rate of acetate esters, which allows for the selective hydrolysis of the PPXEM-g-PVClAc brush precursor under mild conditions for the preparation of PVA molecular bottlebrushes. ${ }^{[24]}$ The macromolecular structure of the PVA brushes in solution is characterized by small angle X-ray scattering (SAXS) and atomic force microscopy (AFM), showing that the PVA brushes have a rod-like topology. To demonstrate the effect of main chain architecture on the ice-adhesive properties of PVA, the IRI efficacy of the PVA molecular bottlebrushes is measured and compared to the efficacy of linear PVA. The results show that the PVA bottlebrush is similarly efficient in slowing down Ostwald ripening processes as compared to linear PVA. Even though the PVA side chains are densely grafted on a rigid PHEMA backbone, their adhesive properties seem little affected, demonstrating the flexibility of PVA chain architecture for designing synthetic ice growth inhibitors with improved efficacy. Furthermore, the facile synthesis and selective hydrolysis of chloroacetate esters described in this work may also offer a new methodology to develop complex PVA architectures for uses in coating industries or emulsifiers.

\section{Experimental Section}

\subsection{Chemicals and Materials}

All commercial reagents were purchased from Sigma-Aldrich and used as received without further purification, unless stated otherwise. Vinyl ester monomers were purified by passing through basic alumina prior to polymerization. Azobisisobutyronitrile (AIBN, Sigma-Aldrich) was recrystallized from methanol. $N$-ethyl- $N$-(3-dimethylaminopropyl)carbodiimide hydrochloride (EDC) was purchased from Iris Biotech. Deuterated solvents were obtained from Cambridge Isotope Laboratories and dried over molsieves. All solvents were of analytical reagent (AR) quality and purchased from Biosolve. All polymerization reactions were performed using a $10 \mathrm{~mL}$ Schlenk flask (Chemglass, AF-0520-20). Reactions were followed by thin-layer chromatography (precoated $0.25 \mathrm{~mm}, 60-\mathrm{F} 254$ silica gel plates from Merck).

\subsection{Instrumentation}

Flash chromatography was performed using an automatic flash chromatography instrument, Biotage Isolera One, equipped with Biotage SNAP KP-Sil silica cartridges. NMR spectroscopy was performed on a Varian Mercury Vx $400 \mathrm{MHz}$ and/or Varian 400MR, operating at $400 \mathrm{MHz}$ for ${ }^{1} \mathrm{H}$ and $100 \mathrm{MHz}$ for ${ }^{13} \mathrm{C}$. Chemical shifts are reported in ppm ( $\delta$ ) values relative to tetramethylsilane (TMS) or residual solvent. Splitting patterns are labeled as s, singlet; d, doublet; dd, double doublet; t, triplet; q, quartet; q, quintet; $m$, multiplet; and b stands for broad. IR spectra were recorded on a PerkinElmer Fourier transform infrared spectroscopy (FTIR) Spectrum 2 spectrometer equipped with a PerkinElmer Universal ATR Sampler Accessory. Gel permeation chromatography with dimethylformamide as eluent (DMF-GPC) measurements were carried out on a PL-GPC-50 plus from Polymer Laboratories (Agilent Tech.) with refractive index detector working in DMF containing $10 \times 10^{-3} \mathrm{M} \mathrm{LiBr}$ at $50{ }^{\circ} \mathrm{C}$ at a constant flow rate of

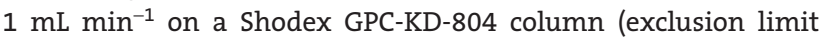
$=400 \mathrm{kDa} ; 0.8 \mathrm{~cm}$ i.d. $\times 300 \mathrm{~mL}$ ), which was calibrated with polyethyleneoxide (PEO) standards with a range from 282-77 $350 \mathrm{Da}$ (Polymer Laboratories, Agilent Tech.). GPC with tetrahydrofuran as eluent (THF-GPC) measurements were performed on a Shimadzu system (Prominence i LC-2030C 3D) equipped with 
two Agilent Technology columns in series (PLgel $5 \mu \mathrm{m}$ mixed C [200-2 $000000 \mathrm{Da}$ ] and PLgel $5 \mu \mathrm{m}$ mixed D [200-40 $000 \mathrm{Da}])$, a RI detector and a PDA detector, with THF as eluent at $40{ }^{\circ} \mathrm{C}$ and

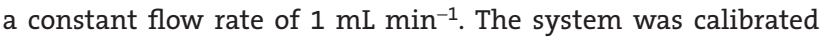
with polystyrene (PS) samples with a range of 580-100 $000 \mathrm{Da}$ (Polymer Laboratories). The morphology of the molecular brushes is investigated by AFM by means of topography as well as phase imaging. The material is drop cast on highly ordered pyrolytic graphite (HOPG). The measurements are performed in tapping mode on a NTegra Aura (NT-MDT) using a Hi'Res $\mathrm{C} 14 / \mathrm{Cr}-\mathrm{Au}$ cantilever (MikroMasch) with a typical spike radius of $1 \mathrm{~nm}$, spring constant $5 \mathrm{~N} \mathrm{~m}^{-1}$ and resonance frequency of $160 \mathrm{KHz}$. Synchrotron radiation X-ray scattering data was collected at the BM29 BioSAXS beamline of the ESRF (Grenoble, France) operating at $12.5 \mathrm{keV}$. The scattering intensity was measured as a function of momentum transfer vector $q=4 \pi(\sin \theta) / \lambda$, where $\lambda=0.992 \AA$ is the radiation wavelength and $2 \theta$ is the scattering angle. The beam size was set to about $700 \mu \mathrm{m} \times 700 \mu \mathrm{m}$ and twodimensional scattering profiles were collected using a Pilatus $1 \mathrm{M}$ detector. Samples were measured at a fixed sample-to-detector distance of $2.867 \mathrm{~m}$ to cover an angular range of $0.03-5 \mathrm{~nm}^{-1}$. Samples were loaded via an automated sample changer and flowed through a quartz capillary $1.8 \mathrm{~mm}$ in diameter, while collecting ten frames of $0.1 \mathrm{~s}$ with a reduced flux of $10^{12} \mathrm{ph} \mathrm{s}^{-1}$. The averaged value of buffer scattering measured before and after the sample measurements was subtracted from the averaged sample scattering curve. Samples were measured at $5 \mathrm{mg} \mathrm{mL}^{-1}$ and the scattering profiles were brought to absolute scale using the known scattering cross-section per unit sample volume, $\mathrm{d} \Sigma / \mathrm{d} \Omega(0)$, of water and verified using a bovine serum albumin (BSA) protein standard. The ice recrystallization inhibition experiments were performed as described elsewhere. ${ }^{[25]}$

\subsection{Preparation of Copper Chlorides}

\subsubsection{Copper(I) Chloride}

In a $100 \mathrm{~mL}$ beaker, a solution was prepared of powdered $\mathrm{CuSO}_{4}^{-}$ 5-hydrate $(6 \mathrm{~g}, 24 \mathrm{mmol})$ and $\mathrm{NaCl}(1.8 \mathrm{~g}, 30 \mathrm{mmol})$ in $20 \mathrm{~mL}$ of hot water. A solution of $\mathrm{NaHSO}_{3}(1.4 \mathrm{~g}, 13 \mathrm{mmol})$ and $\mathrm{NaOH}$ ( $0.9 \mathrm{~g}, 23 \mathrm{mmol})$ in $10 \mathrm{~mL}$ water was added drop-wise to the stirring copper sulfate solution. The cuprous chloride was allowed to settle and the liquid decanted. The precipitated cuprous chloride was washed two times with water by decantation, subsequently filtered and washed with ethanol and diethyl ether. The cuprous chloride is obtained as a white powder that darkens to greenbrown on exposure to air.

\subsubsection{Copper(II) Chloride}

$\mathrm{CuCl}_{2}$ hydrate was dried in a vacuum oven over $\mathrm{P}_{2} \mathrm{O}_{5}$ at $80-100{ }^{\circ} \mathrm{C}$ for $2-3 \mathrm{~h}$, resulting in brown crystals. Copper chlorides were stored under argon in a desiccator.

\subsection{Preparation of 4-(Dimethylamino)pyridinium 4-Toluenesulfonate}

Hydrated $p$-toluenesulfonic acid (1.96 g, $16 \mathrm{mmol}$ ) in toluene was dried by azeotropic distillation by using a Dean-Stark trap. ${ }^{[26]}$
An equimolar solution of 4-dimethylaminopyridine (3.04 g, $16 \mathrm{mmol}$ ) in warm toluene was added drop-wise to the hot mixture. The resulting suspension is cooled and the solid collected by filtration. The crude product was purified by recrystallization from hot acetone (4.32 g, 86\%). ${ }^{1} \mathrm{H}$ NMR (400 $\left.\mathrm{MHz}, \mathrm{CDCl}_{3}, \delta\right): 8.19$ (t, $J=5.6 \mathrm{~Hz}, 2 \mathrm{H}, \mathrm{Ar}-H$ ), 7.83 (d, $J=8.1 \mathrm{~Hz}, 2 \mathrm{H}, \mathrm{Ar}-H), 7.18$ (d, $J=7.9$ $\mathrm{Hz}, 2 \mathrm{H}, \mathrm{Ar}-\mathrm{H}), 6.77$ (d, $J=7.9 \mathrm{~Hz}, 2 \mathrm{H}, \mathrm{Ar}-\mathrm{H}), 3.19$ (s, $\left.6 \mathrm{H} \mathrm{N}\left(\mathrm{CH}_{3}\right)_{2}\right)$, 2.34 (s, 3H, $\left.\mathrm{Ar}-\mathrm{CH}_{3}\right)$.

\subsection{Xanthogenic Acid}

To a $250 \mathrm{~mL}$ round bottom flask were added potassium ethyl xanthogenate ( $20 \mathrm{~g}, 125 \mathrm{mmol})$, 2-bromopropionic acid $(7.4 \mathrm{~mL}$, $82 \mathrm{mmol}$ ), and $150 \mathrm{~mL}$ acetone, and stirred for $24 \mathrm{~h}$ at room temperature (RT). The salt was filtered from the solution and the solvent removed under reduced pressure, yielding the final product as a yellow oil at $95 \%$ purity. ${ }^{1} \mathrm{H} \mathrm{NMR}\left(400 \mathrm{MHz}, \mathrm{CDCl}_{3}, \delta\right): 10.52(\mathrm{~s}, 1 \mathrm{H}$, $\mathrm{COOH}$ ) 4.61 (q, $\left.J=7.1 \mathrm{~Hz}, 2 \mathrm{H}, \mathrm{OCH}_{2} \mathrm{CH}_{3}\right), 4.31$ (q, J=7.4, Hz, $1 \mathrm{H}$, $\left.(\mathrm{CO}) \mathrm{CH}\left(\mathrm{CH}_{3}\right) \mathrm{S}\right), 1.54\left(\mathrm{~d}, J=7.4 \mathrm{~Hz}, 3 \mathrm{H},(\mathrm{CO}) \mathrm{CH}\left(\mathrm{CH}_{3}\right) \mathrm{S}\right), 1.41$ (t, $J=$ $\left.7.1 \mathrm{~Hz}, 3 \mathrm{H}, \mathrm{OCH}_{2} \mathrm{CH}_{3}\right) .{ }^{13} \mathrm{C} \mathrm{NMR}\left(100 \mathrm{MHz}, \mathrm{CDCl}_{3}, \delta\right): 213.4,176.5$, $70.1,49.7,18.0,13.8$.

\subsection{Poly(hydroxyethyl methacrylate)}

A clean and dry $10 \mathrm{~mL}$ Schlenk flask was charged with 2-(trimethylsiloxy)ethyl methacrylate (HEMA-TMS, 400 eq., $5 \mathrm{~mL}, 22.93 \mathrm{mmol}$ ), 4,4'-dinonyl-2,2'-dipyridyl (dNbpy, 4.4 eq., $103 \mathrm{mg}, 0.252 \mathrm{mmol}$ ), $\mathrm{CuCl}$ (2 eq., $11 \mathrm{mg}, 0.115 \mathrm{mmol}$ ), $\mathrm{CuCl}_{2}$ (0.2 eq., $1.5 \mathrm{mg}, 11 \mathrm{mmol}$ ), and anisole $(10 \mathrm{v} / \mathrm{v} \%, 0.56 \mathrm{~mL})$. The flask was deoxygenated by three freeze-pump-thaw (FPT) cycles. After the final cycle, the flask was filled with argon and ethyl- $\alpha$ bromoisobutyrate (EBriB, 1 eq., $8.4 \mu \mathrm{L}, 0.057 \mathrm{mmol}$ ) was quickly added, followed by another FPT-cycle. The flask was again backfilled with argon and immersed in an oil bath at $90{ }^{\circ} \mathrm{C}$. The reaction was stopped after $1.5 \mathrm{~h}$ at $42 \%$ monomer conversion ( ${ }^{1} \mathrm{H} \mathrm{NMR}$, $\left.\mathrm{CDCl}_{3}\right)$ via exposure to air. $\mathrm{GPC}\left(\mathrm{CHCl}_{3}\right.$, poly(methyl methacrylate) (PMMA) standard): $M_{n, G P C}=22.300, D P=109, \boxplus=1.10$. The reaction mixture was diluted with chloroform and the copper was removed by passing the reaction mixture through a silica column. The chloroform was removed under reduced pressure, after which $20 \mathrm{~mL}$ methanol was added to the reaction aliquot and $1.7 \mathrm{~mL}$ of $37 \% \mathrm{HCl}$ solution to give a final $1 \mathrm{~m}$ methanolic $\mathrm{HCl}$ solution to deprotect the TMS groups. The reaction mixture was stirred overnight at RT, after which the solution was neutralized by the addition of $1.7 \mathrm{~mL}$ of a $1 \mathrm{M} \mathrm{NaOH}$ solution and the methanol removed under vacuum. The final polymer solution was precipitated in THF and dried under vacuum. GPC (DMF, PEO standard): $M_{\mathrm{n}}=$ 17,000, DP $=129, \oplus=1.08 .{ }^{1} \mathrm{H}$ NMR (400 MHz, DMSO- $d_{6}, \delta$ ): 4.29 (b, $1 \mathrm{H}, \mathrm{OH}$ ), 3.88 (b, $2 \mathrm{H}, \mathrm{CH}_{2} \mathrm{CH}_{2} \mathrm{OH}$ ), 3.57 (b, $2 \mathrm{H}, \mathrm{CH}_{2} \mathrm{CH}_{2} \mathrm{OH}$ ), 1.77 (b, $\left.2 \mathrm{H}, \mathrm{CH}_{2} \mathrm{C}\left(\mathrm{CH}_{3}\right) \mathrm{C}=\mathrm{O}\right), 0.92,0.76$ (b, 3H, $\mathrm{CH}_{2} \mathrm{C}\left(\mathrm{CH}_{3}\right) \mathrm{C}=\mathrm{O}$ ).

\subsection{Poly(2-propionyloxyethylxanthateetyl methacrylate)}

PHEMA (0.5 g, 3.77 mmol HEMA unit), 4-(dimethylamino)pyridinium 4-toluenesulfonate (DPTS) $(1.11 \mathrm{~g}, 3.77 \mathrm{mmol})$, and xanthogenic acid (XA) $(2.2 \mathrm{~g}, 11.31 \mathrm{mmol})$ were dissolved in $20 \mathrm{~mL}$ dry DMSO. EDC (1.95 g, $10.18 \mathrm{mmol}$ ) in $5 \mathrm{~mL}$ chloroform was added drop-wise to the reaction mixture and left to stir for $2 \mathrm{~d}$

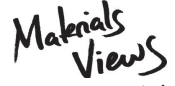

www.MaterialsViews.com 
at RT. Chloroform (150 mL) was added to the reaction mixture and the solution was washed twice with $1 \% \mathrm{NaHCO}_{3}$ solution and four times with water $(100 \mathrm{~mL})$. The organic layer was dried over $\mathrm{MgSO}_{4}$ and the chloroform was removed under reduced pressure. The polymer was precipitated in pentane three times. The final product was stored at $4{ }^{\circ} \mathrm{C}$ in chloroform and only dried directly before use. Nearly full functionalization was observed by ${ }^{1} \mathrm{H} \mathrm{NMR}\left(\mathrm{CDCl}_{3}\right)$. A small shoulder is present in the GPC trace attributed to minimal crosslinking, which is not observable by ${ }^{1} \mathrm{H}$ NMR. GPC (THF, PMMA standard): $M_{\mathrm{n}, \mathrm{GPC}}=37400, \mathrm{DP}=121$, $\boxplus=1.56 .{ }^{1} \mathrm{H}$ NMR $\left(400 \mathrm{MHz}, \mathrm{CDCl}_{3}, \delta\right): 4.63$ (b, $\left.2 \mathrm{H}, \mathrm{CH}_{3} \mathrm{CH}_{2} \mathrm{O}\right), 4.35$ (b, $\left.2 \mathrm{H}+1 \mathrm{H}, \mathrm{OCH}_{2} \mathrm{CH}_{2} \mathrm{O}+\mathrm{SCH}\left(\mathrm{CH}_{3}\right) \mathrm{C}=\mathrm{O}\right), 4.17\left(\mathrm{~b}, 2 \mathrm{H}, \mathrm{OCH}_{2} \mathrm{CH}_{2} \mathrm{O}\right)$, 1.85 (b, $\left.2 \mathrm{H}, \mathrm{CH}_{2} \mathrm{C}\left(\mathrm{CH}_{3}\right) \mathrm{C}=\mathrm{O}\right), 1.61\left(\mathrm{~d}, J=6.6 \mathrm{~Hz}, 3 \mathrm{H}, \mathrm{SCH}\left(\mathrm{CH}_{3}\right) \mathrm{C}=\mathrm{O}\right)$, 1.42 (t, $J=7.1 \mathrm{~Hz}, 3 \mathrm{H}, \mathrm{CH}_{3} \mathrm{CH}_{2} \mathrm{O}$ ), 1.06, 0.89 (b, 3H, $\mathrm{CH}_{2} \mathrm{C}\left(\mathrm{CH}_{3}\right) \mathrm{C}=\mathrm{O}$ ).

\subsection{Synthesis of PPXEM-g-PVA Bottlebrush}

A clean and dry $10 \mathrm{~mL}$ Schlenk flask was charged with $2 \mathrm{~mL}$ VClAc (250 eq. of XA group, $19.8 \mathrm{mmol}$ ), PPXEM (24 mg, $0.079 \mathrm{mmol}$ XA group), AIBN (0.2 eq. of XA group, $2.6 \mathrm{mg}, 0.016 \mathrm{mmol}$ ), and dioxane $(10 \mathrm{v} / \mathrm{v} \%, 0.22 \mathrm{~mL})$. The flask was deoxygenated by three freeze-pump-thaw cycles, back-filled with argon and immersed in an oil back at $60{ }^{\circ} \mathrm{C}$. The reaction progress was followed by ${ }^{1} \mathrm{H}$ NMR and stopped after $6 \mathrm{~h}$ at $42 \%$ conversion. The polymer was precipitated in pentane three times and dialyzed (THF, Spectra/Por RC-membrane 12-14 kDa MWCO). The polymer was dried under high vacuum for $3-4 \mathrm{~h}$, and the resulting product had a solid white appearance. GPC (THF, PS standards): $M_{\mathrm{n}}=471800, \nexists=1.07 .{ }^{1} \mathrm{H}$ NMR (400 MHz, $\mathrm{CDCl}_{3}, \delta$ ): 4.95 (b, $1 \mathrm{H}, \mathrm{CH}_{2} \mathrm{CHO}$ ), 4.10 (b, 2H, $\mathrm{ClCH}_{2}(\mathrm{C}=\mathrm{O})$, $1.92\left(\mathrm{~b}, 2 \mathrm{H}, \mathrm{CH}_{2} \mathrm{CHO}\right)$. The polymer was hydrolyzed by dissolving $50 \mathrm{mg}$ in $5 \mathrm{~mL} \mathrm{THF} / \mathrm{MeOH}$ followed by additional $10 \mathrm{mg} \mathrm{K}_{2} \mathrm{CO}_{3}$ and was stirred for $2 \mathrm{~h}$ at RT. The solvent was removed under reduced pressure. The yellow-orange product was redissolved in water and dialyzed (CE, 100-500 Da MWCO) to remove residual salt. ${ }^{1} \mathrm{H}$ NMR (400 MHz, DMSO- $\left.d_{6}, \delta\right): 4.72 \mathrm{~mm}, 4.58 \mathrm{mr}, 4.34 \mathrm{rr}$ (triad, $1 \mathrm{H}, \mathrm{OH}$ ), 3.84 (b, $\left.1 \mathrm{H}, \mathrm{CH}_{2} \mathrm{CHOH}\right), 1.37$ (b, 2H, $\left.\mathrm{CH}_{2} \mathrm{CHOH}\right)$.

\subsection{Synthesis of Linear Poly(vinyl alcohol) via RAFT Polymerization of $\mathrm{VClAC}$}

A clean and dry $10 \mathrm{~mL}$ Schlenk flask was charged with $5 \mathrm{~mL}$ of vinyl ester monomer (250 eq.), cyanomethyl methyl(phenyl)

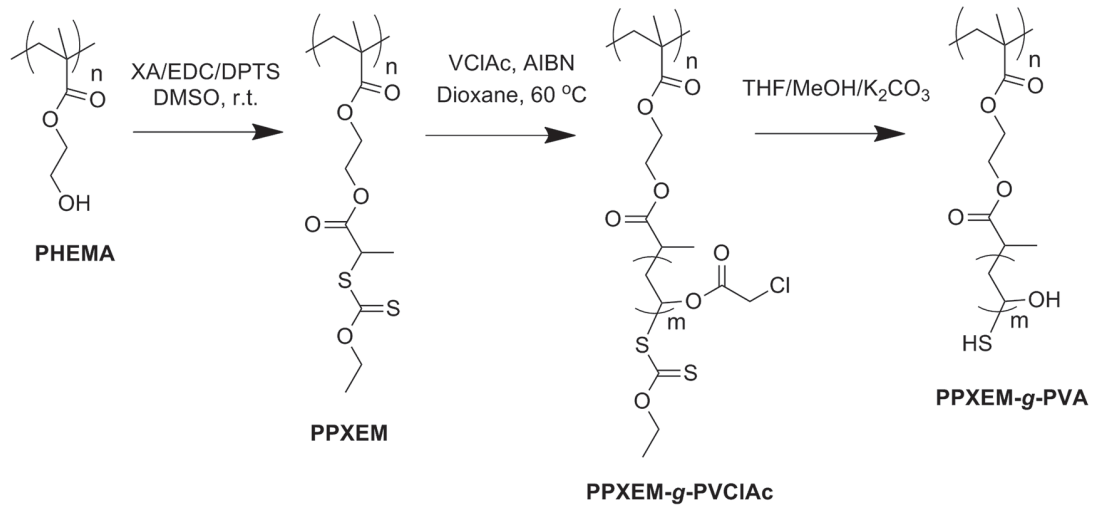

Scheme 1. Synthesis of PVA brush (PPXEM- $g$-PVA), with degree of polymerization of the polymer backbone $n \approx 129$ and side chains $m \approx 105$. carbamodithioate (CTA, 1 eq.), AIBN (0.2 eq.), and dioxane $(10 \mathrm{v} / \mathrm{v} \%, 0.56 \mathrm{~mL})$. The flask was deoxygenated by three freezepump-thaw cycles, back-filled with argon and immersed in an oil back at $60{ }^{\circ} \mathrm{C}$. The monomer conversion was checked by ${ }^{1} \mathrm{H}$ NMR $\left(\mathrm{CDCl}_{3}\right)$ and the reaction stopped after $18 \mathrm{~h}$ at $38 \%$ conversion by exposure to air. The reaction mixture was diluted with THF and the polymer precipitated three times in pentane, except PVPi which was precipitated in $\mathrm{MeOH} /$ water. The product was dried under high vacuum for 3-4 h. The molecular weights were checked by GPC. GPC (THF, PS standards): $M_{\mathrm{n}}=10650, \mathrm{DP}=88$, $\mathrm{D}=1.55 .{ }^{1} \mathrm{H} \mathrm{NMR}\left(400 \mathrm{MHz}, \mathrm{CDCl}_{3}, \delta\right): 4.96$ (b, $\left.1 \mathrm{H}, \mathrm{CH}_{2} \mathrm{CHO}\right), 4.10$ (b, $2 \mathrm{H}, \mathrm{ClCH}_{2}(\mathrm{C}=\mathrm{O}), 1.93$ (b, 2H, $\mathrm{CH}_{2} \mathrm{CHO}$ ). The polymer was hydrolyzed by dissolving $50 \mathrm{mg}$ in $5 \mathrm{~mL} \mathrm{THF} / \mathrm{MeOH}$ followed by additional $10 \mathrm{mg} \mathrm{K}_{2} \mathrm{CO}_{3}$ and was stirred for $2 \mathrm{~h}$ at RT. The solvent was removed under reduced pressure. The product was redissolved in water and dialyzed (CE, 100-500 Da MWCO) to remove residual salt. The polymers were dried under high vacuum at RT for 3-4 h. ${ }^{1} \mathrm{H}$ NMR (400 MHz, DMSO- $d_{6}, \delta$ ): $4.67 \mathrm{~mm}, 4.47 \mathrm{mr}, 4.22 \mathrm{rr}$ (triad, $1 \mathrm{H}, \mathrm{OH}), 3.83$ (b, 1H, $\left.\mathrm{CH}_{2} \mathrm{CHOH}\right), 1.37$ (b, 2H, $\mathrm{CH}_{2} \mathrm{CHOH}$ ).

\section{Results and Discussion}

\subsection{Preparation of PPXEM Macro-CTA}

The reaction conditions and stoichiometry of reagents for the ATRP polymerization of HEMA-TMS were chosen according to an adapted procedure which was developed to target high molecular weight, involving halogen exchange to improve initiation efficiency. The initial stoichiometry of the reagents was: [HEMA-TMS]:[EBriB]:[CuCl]:[CuCl$\left.{ }_{2}\right]$ : $[\mathrm{dNbpy}]=400: 1: 2: 0.2: 4.4$, with $10 \mathrm{v} / \mathrm{v} \%$ anisole at $T=90^{\circ} \mathrm{C}$. Monomer conversion was monitored by ${ }^{1} \mathrm{H}$ NMR and the polymerization reaction was quenched at $42 \%$ monomer conversion. The copper catalyst was removed by passing the reaction mixture through a silica column. Deprotection of the TMS-groups in methanolic $\mathrm{HCl}$ yielded PHEMA with a molecular weight of $M_{n}=17000, D P=129$, and $Ð=1.08$. The esterification of PHEMA with XA to form the macroCTA PPXEM was performed via EDC/DPTS coupling (Scheme 1). Nearly full conversion was observed from the ${ }^{1} \mathrm{H}$ NMR spectrum (Figure 1 ), and the GPC analysis yielded a molecular weight of $M_{n}=37400, D P=121$, and $\boxplus=1.56$ (Table 1). The increase in dispersity arises from a shoulder toward shorter retention time in the GPC trace, probably due to a very small amount of crosslinking (not observable with ${ }^{1} \mathrm{H}$ NMR) or interactions of PPXEM with the column.

\subsection{Preparation of PVA Bottlebrushes}

PVA molecular bottlebrushes were synthesized by the selective hydrolysis of the PVClAc side chains of PPXEM- $g$-PVClAc 

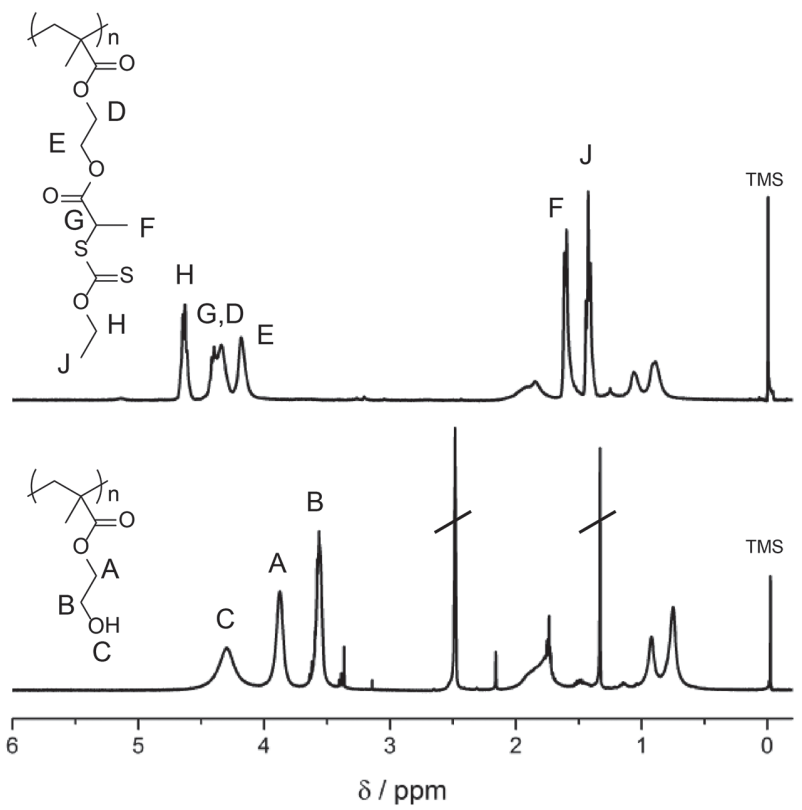

Figure 1. "H NMR of macroCTA PPXEM (top) and PHEMA (bottom) measured in $\mathrm{CDCl}_{3}$ and $d_{6}$-DMSO, respectively.

brushes. RAFT polymerization of the PVClAc side chains using PPXEM as macro-CTA was performed using AIBN ( 0.2 eq. per $X A$ ) as initiator and 250 eq. of monomer per $\mathrm{XA}$ in $10 \mathrm{v} / \mathrm{v} \%$ dioxane. The reaction was allowed to continue for $6 \mathrm{~h}$ at $60{ }^{\circ} \mathrm{C}$ until $42 \%$ conversion, corresponding to a theoretical degree of polymerization of $D P \approx 105$ of the PVClAc side chains. The reaction mixture was already highly viscous at $42 \%$ conversion. The polymer was precipitated in pentane and dialyzed (THF, 12-14 kDa MWCO). The GPC (THF, PS standards) shows two peaks with peak maxima at $t_{\text {top }}=11.02 \mathrm{~min}\left(\mathrm{AUC}=6.9 \%, M_{\mathrm{n}}=471800\right.$, $\boxplus=1.07)$ and $t_{\text {top }}=14.16 \min \left(\mathrm{AUC}=93.1 \%, M_{\mathrm{n}}=11500\right.$, $\boxplus=1.94)$. The first peak $\left(M_{\mathrm{n}}=471800\right)$ corresponds to the apparent molecular weight of the molecular brush. The estimated molecular weight calculated from the monomer conversion is $M_{n}=1672000$. This rather low apparent $M_{n}$ in GPC was also observed for PPXEM- $g$-PVAc molecular

Table 1. Molecular weight and polymer dispersity data of the polymer backbone (PHEMA and PPXEM), PVA bottlebrush precursor (PPXEM- - -PVCIAC), and linear PVA precursor (PVCIAC). Degree of polymerization was determined from the monomer conversion by ${ }^{1} \mathrm{H} N M R$.

\begin{tabular}{lcccc}
\hline & $\begin{array}{c}\boldsymbol{M}_{\mathbf{n}} \mathbf{N M R} \\
{[\mathbf{D a}]}\end{array}$ & $\begin{array}{c}\boldsymbol{M}_{\mathbf{n}} \text { GPC } \\
{[\mathbf{D a}]}\end{array}$ & DP & $\boldsymbol{\Xi}$ \\
\hline PHEMA & 16800 & 17000 & 129 & 1.08 \\
PPXEM & 39700 & 37400 & 121 & 1.56 \\
PPXEM- & 1672000 & 471800 & $129-105^{\mathrm{a})}$ & 1.07 \\
g-PVClAc & & & & \\
PVClAc & 11700 & 10650 & $95^{\mathrm{a})}$ & 1.55
\end{tabular}

a) Calculated from monomer conversion by ${ }^{1} \mathrm{H}$ NMR.

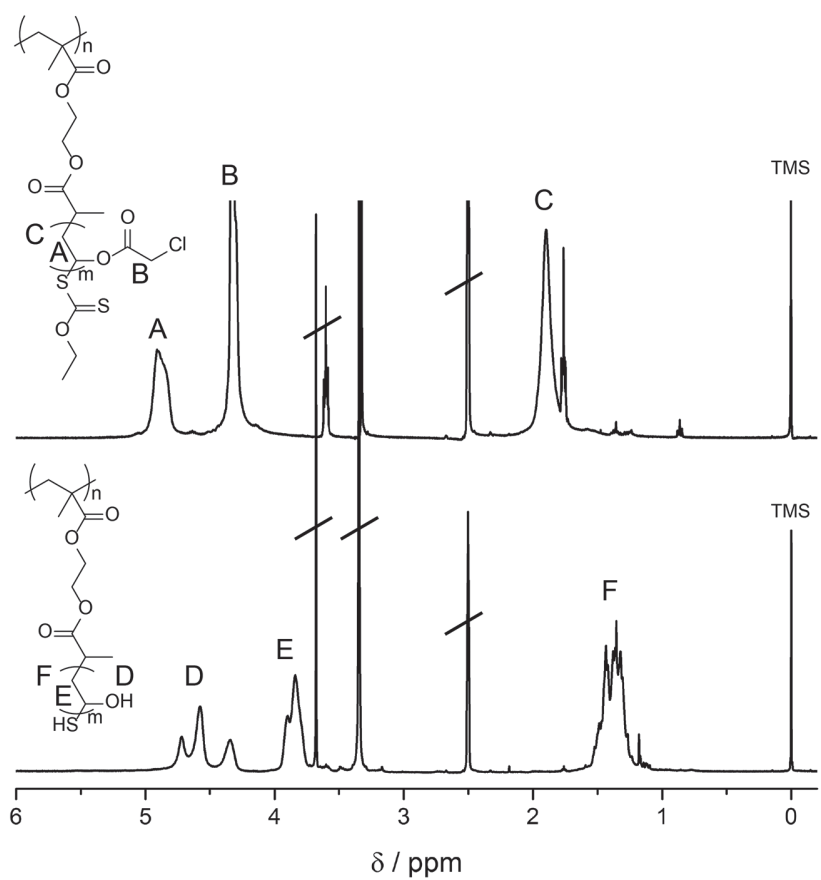

Figure 2. ${ }^{1} \mathrm{H}$ NMR of molecular bottlebrushes PPXEM- $g$-PVCIAC (top) and PPXEM-g-PVA (bottom) measured in $d_{6}$-DMSO.

brushes by Nese et al., in which they found $M_{\mathrm{n}, \mathrm{NMR}}=$ 1880000 and $M_{n, G P C}=315000 .{ }^{[22]}$ The second peak in the GPC trace at $t_{\text {top }}=14.16 \min \left(M_{\mathrm{n}}=11500\right)$ might originate from the brush-like structure and/or interactions of the chlorine groups of the polymer side chains with the column. The PPXEM-g-PVClAc precursor bottlebrush was hydrolyzed under mild conditions using THF $/ \mathrm{MeOH} / \mathrm{K}_{2} \mathrm{CO}_{3}$ at room temperature to yield PPXEM-g-PVA (Scheme 1). ${ }^{1} \mathrm{H}$ NMR spectra of the initial PPXEM- $g$-PVClAc show quantitative hydrolysis of the chloroacetate groups $\mathbf{a}$ and $\mathbf{b}(\delta=$ 4.88 and $4.31 \mathrm{ppm})$, and the $\mathrm{OH}$ triad $\mathrm{d}(\delta=4.58 \mathrm{ppm})$ of the final PPXEM- $g$-PVA brush (Figure 2). Using the length

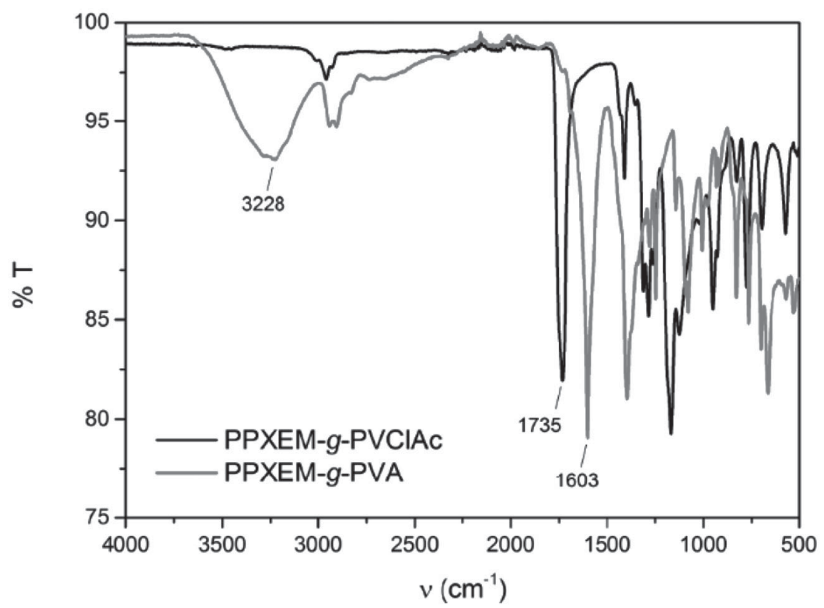

Figure 3. FTIR spectra of the molecular bottlebrushes confirm quantitative hydrolysis of the chloroacetate esters.

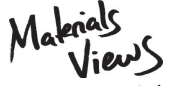

www.MaterialsViews.com 


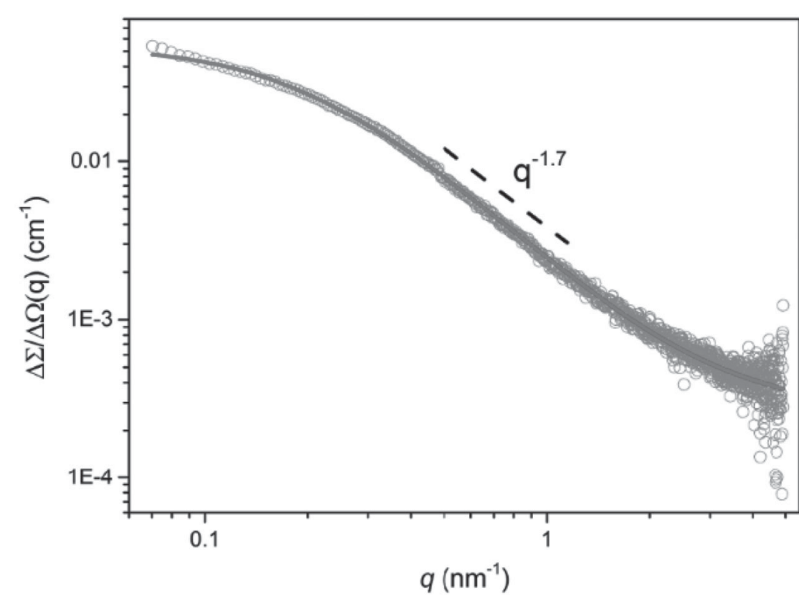

Figure 4. Small angle X-ray scattering (SAXS) data (o) with the apparent power laws indicative of a highly elongated object, and a fit of a polydisperse Gaussian coil model (red line) to the experimental data.

of the polymer backbone consisting of 129 monomers each with a graft compromising 105 units, the molecular weight of the PVA bottlebrush is calculated to be $M_{n}=$ 635700 . Ouantitative hydrolysis of the chloroacetate esters was further confirmed by FTIR spectroscopy (Figure 3), showing the disappearance of the $\mathrm{C}=\mathrm{O}$ stretch vibrational band $v=1735 \mathrm{~cm}^{-1}$ characteristic for the chloroacetate
A

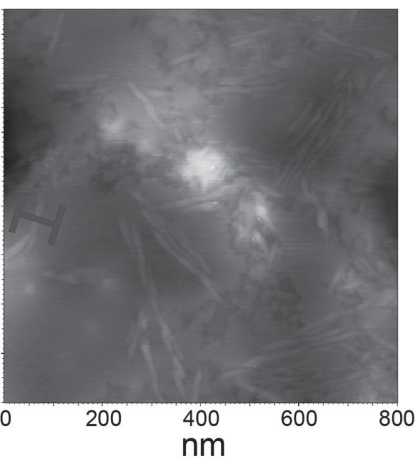

C

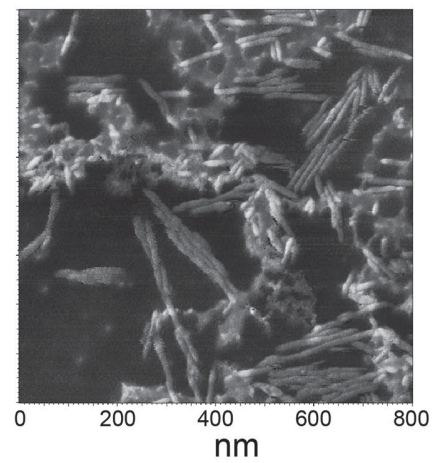

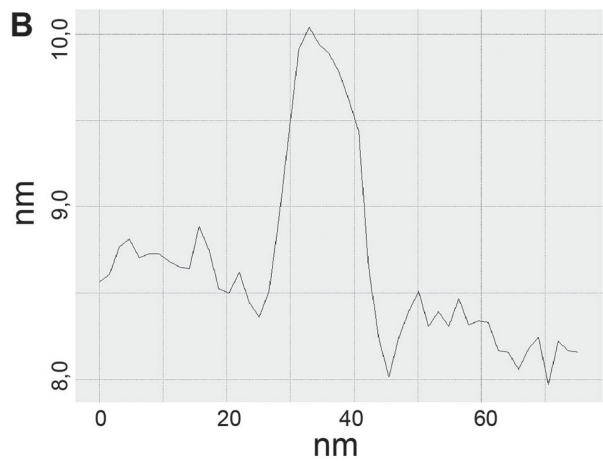

D

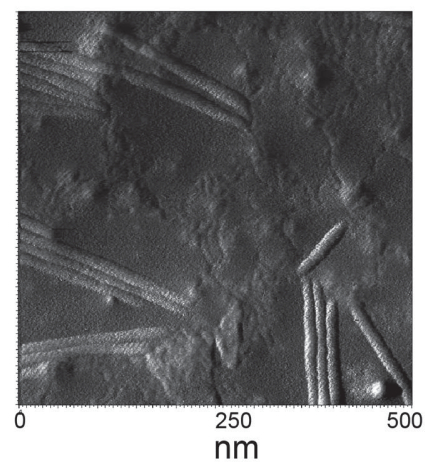

Figure 5. Atomic force microscopy (AFM) images of the PVA brushes. A) Height image within blue is the marked region that is used to plot the $B$ ) height profile of a conglomerate of PVA brush, C) phase image, and D) zoomed-in phase image. PVA brushes (0.1 $\mathrm{mg} \mathrm{mL}^{-1}$ in pure water) were cast on a highly ordered pyrolytic graphite (HOPG) substrate and the solvent was evaporated under a nitrogen stream. esters and formation of the broad $\mathrm{OH}$ stretch vibrational band $v=3228 \mathrm{~cm}^{-1}$ of the hydroxyl groups of the PVA side chains. The vibrational band at $v=1603 \mathrm{~cm}^{-1}$ might arise from the formation of a conjugated unsaturated aldehyde side product, which is promoted by the formation of a reactive aldehyde that was generated from the hydrolysis of the xanthate end-group. ${ }^{[2]}$ However, the latter is not observable in the ${ }^{1} \mathrm{H}$ NMR spectrum.

\subsection{Structural Characterization of the PVA Molecular Bottlebrush}

The macromolecular structure and dimensions of the PVA bottlebrushes were further characterized using SAXS and AFM. Based on the length of the $\mathrm{C}-\mathrm{C}-\mathrm{C}$ monomeric unit in tetrahedral configuration $\left(l_{0}=0.25 \mathrm{~nm}\right)^{[22]}$ and a backbone $\mathrm{DP}=129$, the estimated number-average contour length of the PVA brush approximates $l_{\mathrm{n}}=32 \mathrm{~nm}$. Synchrotron SAXS data of the PVA molecular bottlebrush were obtained on the BM29 beamline (ESRF, Grenoble, France) (Figure 4). The accessible $q$-range does not cover the full scattering profile of the PVA brush, and low- $q$ data points needed to provide a reliable Guinier analysis to extract the radius of gyration $\left(R_{\mathrm{g}}\right)$ and molecular weight $\left(M_{\mathrm{w}}\right.$ SAXs $)$ are missing. Nevertheless, a power law regime where the intensity falls off with $q^{-0.6}$ is visible in the intermediate $q$-regime, which is indicative of a highly elongated object. Indeed, the experimental data can be described by a polydisperse Gaussian coil (PGC) model, which calculates an empirical functional form for the scattering of a polydisperse polymer chain in a good solvent. ${ }^{[28]}$ Using the PGC model, we obtain a radius of gyration $R_{\mathrm{g}}=9.0 \pm 0.1 \mathrm{~nm}$ and a polydispersity of $Ð=4.1 \pm 0.5$.

In AFM experiments, conglomerates of highly extended, stiff rods with a length of approximately $l=100 \mathrm{~nm}$ are observed (Figure 5). The height profile of a single rod (Figure 5B) shows a height of $h=$ $1 \mathrm{~nm}$. Individual brush copolymers could not be identified in the AFM images, which may be due to the sticky and crystalline nature of the PVA side chains, resulting in the formation of conglomerates during sample preparation.

\subsection{Ice Recrystallization Inhibition Activity of the PVA Molecular Bottlebrush}

The IRI experiments were performed as described previously. ${ }^{[25]}$ Briefly, a $1 \mu \mathrm{L}$ sample droplet of the analyte dissolved 

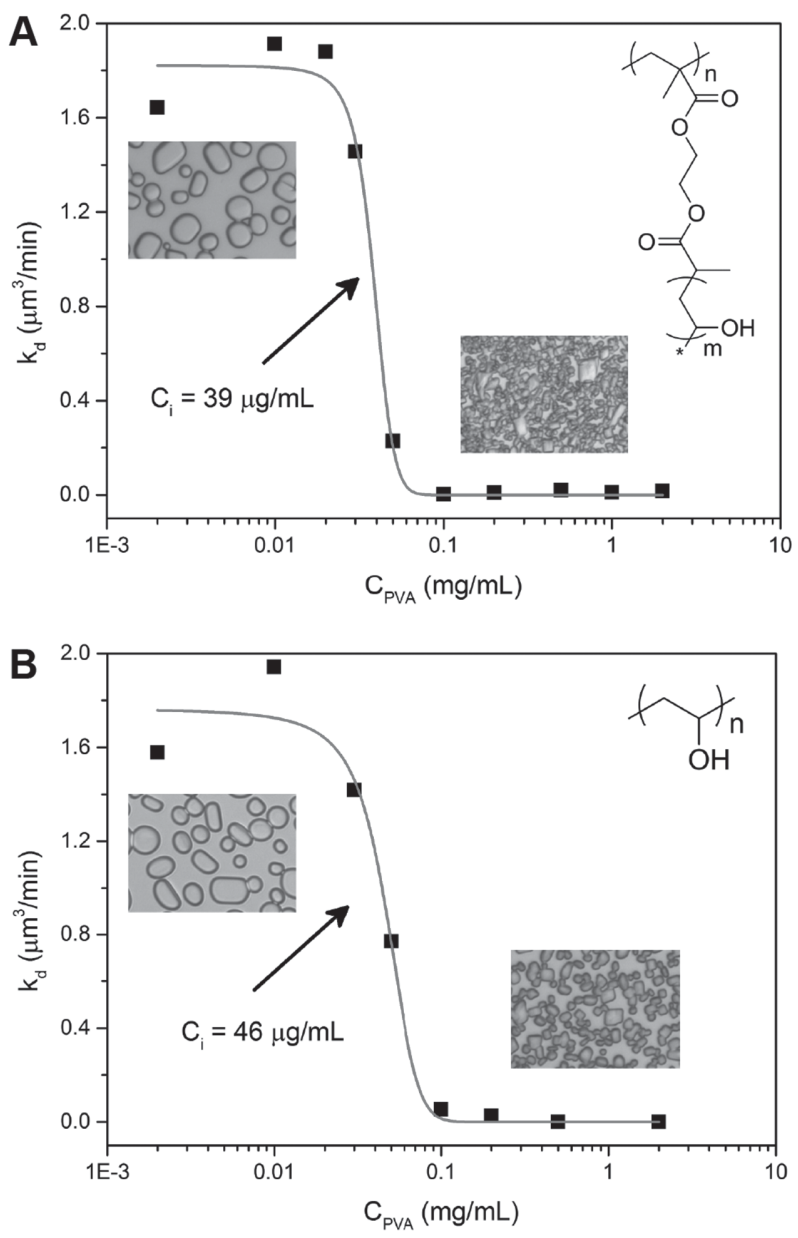

Figure 6. Ice recrystallization inhibition (IRI) experiments of A) PVA bottlebrush and B) linear polymer PVA. Insets are images taken after $90 \mathrm{~min}$ at a concentration of 0.01 and $0.2 \mathrm{mg} \mathrm{mL}^{-1}$. The rate constant of ice recrystallization, $k_{\mathrm{d}}=\frac{r^{3}(t)-r^{3}(t=0)}{t}$, for each polymer concentration is obtained through automated image acquisition and analysis.

in $30 \%$ sucrose is sandwiched between two microscope slides and flash frozen to form a thin ice wafer. The ice wafer is held at $-7{ }^{\circ} \mathrm{C}$ and the recrystallization process monitored for $90 \mathrm{~min}$. Image analysis software that is able to extract circular features from the images is used to determine the grain boundary migration processes of the ice crystals. With this quantitative method, the IRI efficacy $\left(C_{\mathrm{i}}\right)$ of the analyte can be determined. Figure 6 shows the IRI efficacy of the PVA bottlebrush in comparison to linear PVA. The determined IRI efficacy for the linear PVA $\left(C_{\mathrm{i}}=46 \mu \mathrm{g} \mathrm{mL} \mathrm{m}^{-1}\right)$ is in close agreement with reported literature values. ${ }^{[29]}$ Surprisingly, the PVA bottlebrush has a similar IRI efficacy as the linear PVA. Even though the polymer architecture is significantly altered with the PVA side chains of the bottlebrush densely grafted, this does not seem to affect the IRI activity of the polymer.

\subsection{Implications for the Ice Binding of PVA}

Congdon et al. have shown that PVA requires a minimal degree of polymerization of DP $>20$ and a degree of hydrolysis $>80 \%$ to elicit IRI activity. ${ }^{[6]}$ Inada and Lu proposed the binding of PVA to the pyramidal planes of ice, based on the direct observation of the growth habit of a single ice crystal suspended in a PVA solution. ${ }^{[5]}$ On the other hand, Budke and Koop proposed the binding of PVA to the prism planes, since the conformation of the $\mathrm{OH}$ groups of an atactic PVA segment adsorbed on the primary and secondary prism planes of ice matches well with the ice lattice via multiple hydrogen bonds. ${ }^{[4]}$ The spacing between neighboring $\mathrm{C}-\mathrm{O}$ bonds in PVA is $S_{\mathrm{PVA}}=2.52 \AA$, while the spacing between every O-atom in the unit cell of ice is $S_{\text {ice }}=7.36 \AA$, which is $\approx 3 \times S_{\mathrm{PVA}}=7.56 \AA$.

In this work, we aimed to promote the ice binding of PVA through multivalency by densely grafting PVA chains on a rigid polymer backbone. Evidently however, there is no significant difference in IRI efficacy of the PVA bottlebrush and linear PVA with similar PVA chain length. This seems irreconcilable with a direct interaction between PVA and ice. Possibly, the adsorption of PVA onto ice surfaces is promoted via an indirect interaction of clathrate waters hydrogen-bonded to the hydroxyl groups of the polymer, similar to the binding mechanism of antifreeze proteins to ice surfaces. ${ }^{[30-32]}$ Further investigation of the specific hydration of PVA may shed light on the adsorption mechanism of PVA onto ice surfaces.

\section{Conclusions}

This study describes the facile synthesis of a PVA molecular bottlebrush via the RAFT polymerization of PVClAc side chains on a PHEMA backbone, followed by selective hydrolysis of the vinyl chloroacetate esters. The highly extended topology of the PVA bottlebrush is characterized by SAXS and AFM experiments. The IRI efficacy of the PVA bottlebrush was quantitatively compared to linear PVA. Surprisingly, dense grafting of PVA side chains on a rigid polymer backbone hardly affects IRI efficacy. These results demonstrate that the IRI activity of PVA is maintained in complex polymer architectures. The methodology and facile synthesis route of the PVA molecular bottlebrushes described in this work offer new opportunities for the design of other polymer chain architectures for the development of more efficient PVA-based synthetic ice growth inhibitors.

Acknowledgements: This work has financially been supported by the Dutch Science Foundation (NWO Veni grant 700.10.406), the European Union (FP7-PEOPLE-2011-CIG contract 293788, ERC2014-StG contract 635928), and the Dutch Ministry of Education, Culture and Science (Gravity program 024.001.035).

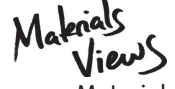

www.MaterialsViews.com 
Received: November 20, 2015; Revised: December 21, 2015; Published online: February 18, 2016; DOI: 10.1002/ macp. 201500497

Keywords: controlled radical polymerization; ice recrystallization inhibition; polymer architecture; poly(vinyl alcohol); molecular bottlebrush

[1] C. DeMerlis, D. Schoneker, Food Chem. Toxicol. 2003, 41, 319.

[2] G. Paradossi, F. Cavalieri, E. Chiessi, C. Spagnoli, M. K. Cowman, J. Mater. Sci.: Mater. Med. 2003, 14, 687.

[3] V. Goodship, D. Jacobs, Polyvinyl Alcohol: Materials, Processing and Applications, Vol. 16 (no. 12), Smithers Rapra Technology, 2009.

[4] C. Budke, T. Koop, ChemPhysChem 2006, 7, 2601.

[5] T. Inada, S.-S. Lu, Chem. Phys. Lett. 2004, 394, 361.

[6] T. Congdon, R. Notman, M. I. Gibson, Biomacromolecules 2013, 14, 1578.

[7] M. I. Gibson, Polym. Chem. 2010, 1, 1141.

[8] R. C. Deller, M. Vatish, D. A. Mitchell, M. I. Gibson, Nat. Commun. 2014, 5.

[9] S.-H. Shim, M.-K. Ham, J. Huh, Y.-K. Kwon, Y.-J. Kwark, Polym. Chem. 2013, 4, 5449.

[10] H. Ohgi, T. Sato, Macromolecules 1999, 32, 2403.

[11] Y. Nagara, K. Yamada, T. Nakano, Y. Okamoto, Polym. J. 2001, 33, 534 .

[12] S. Habaue, Y. Okamoto, Chem. Rec. 2001, 1, 46.

[13] S. Harrisson, X. Liu, J.-N. Ollagnier, O. Coutelier, J.-D. Marty, M. Destarac, Polymers 2014, 6, 1437.

[14] A. L. DeVries, S. K. Komatsu, R. E. Feeney, J. Biol. Chem. 1970, 245, 2901.
[15] Y. Tachibana, G. L. Fletcher, N. Fujitani, S. Tsuda, K. Monde, S. I. Nishimura, Angew. Chem. 2004, 116, 874.

[16] P. Czechura, R. Y. Tam, E. Dimitrijevic, A. V. Murphy, R. N. Ben, J. Am. Chem. Soc. 2008, 130, 2928.

[17] A. Gregory, M. H. Stenzel, Prog. Polym. Sci. 2012, 37, 38.

[18] G. Moad, E. Rizzardo, S. H. Thang, Aust. J. Chem. 2012, 65, 985.

[19] K. Matyjaszewski, N. V. Tsarevsky, Nat. Chem. 2009, 1, 276.

[20] K. Matyjaszewski, Macromolecules 2012, 45, 4015.

[21] S. S. Sheiko, B. S. Sumerlin, K. Matyjaszewski, Prog. Polym. Sci. 2008, 33, 759.

[22] A. Nese, Y. Kwak, R. Nicolaÿ, M. Barrett, S. S. Sheiko, K. Matyjaszewski, Macromolecules 2010, 43, 4016.

[23] A. Nese, Y. Li, S. Averick, Y. Kwak, D. Konkolewicz, S. S. Sheiko, K. Matyjaszewski, ACS Macro Lett. 2011, 1, 227.

[24] M. H. Repollet-Pedrosa, R. L. Weber, A. L. Schmitt, M. K. Mahanthappa, Macromolecules 2010, 43, 7900.

[25] L. L. Olijve, I. K. Voets, under review.

[26] J. S. Moore, S. I. Stupp, Macromolecules 1990, 23, 65.

[27] Y. Y. Tong, Y. O. Dong, F. S. Du, Z. C. Li, J. Polym. Sci., Part A: Polym. Chem. 2009, 47, 1901.

[28] Small Angle X-ray Scattering (Ed: O. Glatter, O. Kratky), Vol. 102, Academic Press, London 1982.

[29] C. Budke, A. Dreyer, J. Jaeger, K. Gimpel, T. Berkemeier, A. S. Bonin, L. Nagel, C. Plattner, A. L. DeVries, N. Sewald, Cryst. Growth Des. 2014, 14, 4285.

[30] C. P. Garnham, R. L. Campbell, P. L. Davies, Proc. Natl. Acad. Sci. USA 2011, 108, 7363.

[31] T. Sun, F.-H. Lin, R. L. Campbell, J. S. Allingham, P. L. Davies, Science 2014, 343, 795.

[32] K. Meister, S. Strazdaite, A. L. DeVries, S. Lotze, L. L. Olijve, I. K. Voets, H. J. Bakker, Proc. Natl. Acad. Sci. 2014, 111, 17732. 